\title{
CONSTITUENTS OF SUSTAINABLE DEVELOPMENT INDUSTRY ENTERPRISES
}

\author{
Karavan N.A. \\ Dniprovsk State Technical University \\ Ukraine, 51918, Kamianske, Dniprobudivska str., 2 \\ karavan_eco@ukr.net \\ ORCID 0000-0002-6845-7862
}

\section{Key words:}

sustainable development, components, indicators, integrated assessment, aggregate index, factor analysis.

\begin{abstract}
Approaches to allocation of functional components of sustainable development of industrial enterprises are investigated. It is emphasized that the substantiation of the content of individual components of sustainable development of industrial enterprises should be based on the national strategy of sustainable development. In terms of the issue under study, the following goals of the sustainable development strategy were identified and analyzed: "Decent work and economic growth"; "Industry. Innovation and structure"; Responsible Consumption and Production. The tasks, indicators and their importance for achieving the goals that should be taken into account when substantiating the content of sustainable enterprise development are highlighted. It is suggested to evaluate the sustainable development of industrial enterprises by the following functional components: economic, industrial, social and environmental. It is concluded that not only quantitative but also qualitative indicators need to be involved in order to realize the detailed characterization of certain functional components of sustainable development. Quantitative indicators are standardized. It is proposed to adopt as a normative an economically feasible level of an indicator, or a level that is desirable for an individual enterprise, taking into account its features and stage of development. Qualitative indicators can only take on two fundamental values: 'satisfactory level' or 'unsatisfactory level'. The methodology of integrated assessment of sustainable development of industrial enterprises is proposed, based on the definition of an aggregate index, the level of which is determined not only by the actual values of the indicators, but also by the direction of their changes. The normative level of the aggregate index is formed by the normative values of quantitative indicators and a satisfactory level of qualitative indicators. The method also provides for the possibility of conducting factor analysis to determine the isolated influence of certain elements of functional components.
\end{abstract}

\section{СКЛАДОВІ СТАЛОГО РОЗВИТКУ ПІДПРИЕМСТВ ПРОМИСЛОВОСТІ}

\section{Караван Н.А.}

Дніпровський державний технічний університет

Украӥна, 51918, м. Кам'янське, вул. Дніпробудівська, 2

\section{Ключові слова:}

сталий розвиток, складові, індикатори, інтегрована оцінка, агрегований індекс, факторний аналіз.
Досліджено підходи до виділення функціональних складових сталого розвитку підприємств промисловості. Наголошено, що обгрунтування змісту окремих складових сталого розвитку підприємств промисловості повинно базуватися на загальнонаціональній стратегії сталого розвитку. Із точки зору питання, що досліджується, виділено та проаналізовано такі цілі стратегії сталого розвитку: „Гідна праця та економічне зростання”; „Промисловість. Інновації та структура”; „Відповідальне споживання та виробництво”. Виокремлено завдання, індикатори та їх значення для досягнення цілей, які повинні бути враховані при обгрунтуванні змісту сталого розвитку підприємств. Запропоновано оцінювати сталий розвиток підприємств промисловості за такими функціональними складовими: економічна, виробнича, соціальна та екологічна. Зроблено висновок, що для здійснення розгорнутої характеристики окремих функціональних складових сталого розвитку необхідно залучити не тільки кількісні, а і якісні індикатори. Кількісні індикатори $€$ нормованими. Як нормативний запропоновано приймати економічно-доцільний рівень показника, або рівень, що $є$ бажаним для окремого підприємства 3 урахуванням його особливостей та етапу розвитку. Якісні індикатори можуть набувати лише двох принципових 
значень: „задовільний рівень” або „незадовільний рівень”. Запропоновано методику інтегрованої оцінки сталого розвитку підприємств промисловості, що базується на визначенні агрегованого індексу, рівень якого зумовлюється не тільки фактичними значеннями індикаторів, а й напрямом їх змін. Нормативний рівень агрегованого індексу формують нормативні значення кількісних індикаторів та задовільний рівень якісних індикаторів. Методикою також передбачається можливість проведення факторного аналізу для визначення відокремленого впливу певних елементів функціональних складових.

\section{Statement of the problem}

Ukraine has joined the global process of ensuring sustainable development. During 2016-2017, there was a wide-ranging and comprehensive process of adapting sustainable development goals to the Ukrainian context. The result of this work was the National Sustainable Development Goals (CSD) system, which consists of 86 tasks [1, p.5]. The National Sustainable Development Goals: Ukraine report provides a vision for Ukraine's MDGs. The document proposes 172 indicators for monitoring the progress of the MDGs. Formation of the national level of indicators takes place at the enterprise level. The problem of substantiation of factors, indicators and indicators of evaluation of the functional components of sustainable development of industrial enterprises is of particular relevance in connection with the decrease in the level of production efficiency and the deterioration of the environment.

\section{Analysis of recent studies and publications}

In the economic literature, there are different approaches to identifying the components of sustainable development. So V.V. Gonchar and L.M. The Philippines conducted a study of the system of indicators for internal and external factors. However, the following were identified as internal factors: economic (production and financial), social and environmental [2, p.148]. H.R. Halchak considering the issues of formation of social responsibility in the context of ensuring the sustainable development of the enterprise identified the following internal factors of influence of the enterprise: economic, environmental, social and ethicallegal [3, p.73]. Pokulin S.L. and Pokulin A.A. in the construction of the concept of sustainable development management of the enterprise distinguish factors of external (social, environmental and economic components) and internal (management: innovative, investment, marketing, production, personnel, financial) environment [4, p. 29].

It should also be noted that the assessment of sustainable development factors requires the involvement of certain indicators. It is impossible to disagree with V.V. Gonchar and L.M. Filipino for this reason: “... The use of indicators developed by international organizations requires a large amount of information which in some cases cannot be obtained. There is a need to improve the system of sustainable development assessment which would enable the management of the enterprise and the society to evaluate the effectiveness of the chosen strategy in this context" [2, p.147].
Thus, scientists propose different approaches to the identification and evaluation of factors of sustainable development of industrial enterprises.

\section{Objectives of the article}

Substantiation of functional components of sustainable development of industrial enterprises; systematization of quantitative and qualitative indicators of their evaluation; improving the integrated assessment of sustainable development at the enterprise level.

\section{The main material of the research}

The substantiation of the functional components of the sustainable development of industrial enterprises, in our opinion, should be based on a national strategy for sustainable development. Thus, in the National Report "Sustainable Development Goals: Ukraine", prepared by the Ministry of Economic Development and Trade of Ukraine in 2017, the results of the adaptation of 17 global CSWs were taken into account, taking into account the specifics of national development [5, p. 2]. In terms of the issue under study, we have identified the following: "Decent work and economic growth" (Goal 8); "Industry. Innovation and Structure "(Goal 9); Responsible Consumption and Production (Goal 12). Achieving these and other goals involves completing certain tasks, namely: Goals 8 are six tasks, Goals 9 are seven tasks; Goals 12 to 4 , tasks, etc. To assess the achievement of the objectives, a system of indicators that are targeted by years is proposed: 2015, 2020, 2025 and 2030. The objectives set out in the National Report can only be assessed at the macro level. For example, Objective 8 is to ensure sustainable GDP growth through the modernization of production, the development of innovation, the enhancement of export potential, the launch of high valueadded products on foreign markets; increasing the employment rate of the population; reducing the proportion of young people who do not work, study and acquire professional skills; creation of institutional and financial opportunities for self-realization of the potential of economically active part of the population and development of creative economy [5, p. 62-63].

Table 1 summarizes the tasks, indicators and their target values for the studied purposes, which should be taken into account when substantiating the content of individual functional components of sustainable development of industrial enterprises. 
Table 1 - Tasks, indicators and targets SDG*

\begin{tabular}{|c|c|c|}
\hline & Tasks and indicator & Value for 2020 \\
\hline 1 & 2 & 3 \\
\hline \multirow{8}{*}{ 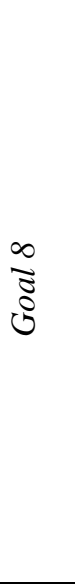 } & $\begin{array}{l}\text { 8.2. Increasing the efficiency of production on the basis of sustainable development } \\
\text { and development of high-tech competitive industries }\end{array}$ & \\
\hline & 8.2.1 The rate of return of fixed assets & 0,26 \\
\hline & 8.2.2. The rate of growth of labor productivity & 104,0 \\
\hline & 8.2.3 GDP intensity & 0,87 \\
\hline & $\begin{array}{l}\text { 8.5. Promoting safe and secure working conditions for all workers, in particular } \\
\text { through the application of innovative technologies in the field of occupational safety } \\
\text { and industrial safety }\end{array}$ & \\
\hline & $\begin{array}{l}\text { 8.5.1. Number of industrial casualties resulting in disability for } 1 \text { working day or } \\
\text { more, } \% \text { to } 2015 \text { level }\end{array}$ & 75 \\
\hline & 8.5.2. Number of casualties, $\%$ of 2015 level & 70 \\
\hline & $\begin{array}{l}\text { 8.5.3. Percentage of workers employed in hazardous working conditions in the total } \\
\text { number of full-time employees }\end{array}$ & 22 \\
\hline \multirow{3}{*}{ 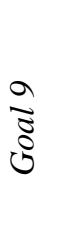 } & $\begin{array}{l}9.5 \text { Creation of financial and institutional system (innovative infrastructure) that will } \\
\text { support the development of research and scientific and technical development }\end{array}$ & \\
\hline & 9.5.1. share of expenditures for scientific and technical works in GDP, $\%$ & 1,50 \\
\hline & $\begin{array}{l}\text { 9.5.2 The share of sold scientific and technical products in the volume of industrial, } \\
\%\end{array}$ & 5,0 \\
\hline \multirow{5}{*}{ 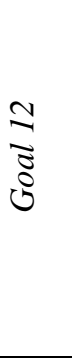 } & 12.1 Reducing the resource intensity of the economy & \\
\hline & 12.1.1 GDP resource intensity, $\%$ up to 2015 level & 90 \\
\hline & $\begin{array}{l}\text { 12.4 Decrease in waste generation and increase in recycling and reuse based on } \\
\text { innovative technologies and industries }\end{array}$ & \\
\hline & $\begin{array}{l}\text { 12.4.1 The volume of generated waste of all types of economic activity per unit of } \\
\text { GDP, } \mathrm{kg} \text { per } 1000 \text { dollars. US for the } 2011 \mathrm{PCB}\end{array}$ & 950 \\
\hline & $\begin{array}{l}\text { 12.4.2. Share of incinerated and reclaimed waste in the total amount of generated } \\
\text { waste, } \%\end{array}$ & 35 \\
\hline
\end{tabular}

* Built by the author according to the data [5]

In our opinion, the main functional components of sustainable development of industrial enterprises should be the following: economic, industrial, social and environmental.

The use of appropriate quantitative and qualitative indicators is proposed to characterize each functional component of the sustainable development of industrial enterprises. Thus, for the economic functional component, indicators characterizing the financial stability, liquidity, profitability and competitiveness of products (by their types) can be adopted as quantitative indicators; for production, the indicators of the condition and mobility of assets, the volume of capital investments, including those with environmental focus; for the social component - labor efficiency, the amount of labor costs, the effectiveness of personnel policy; for the environmental component - the level of harmful effects on the environment, the magnitude of the costs of environmental measures. Quantitative indicators of individual components of sustainable development of the enterprise are grouped in Fig. 1.

Important, in our opinion, is that the implementation of the detailed characteristics of certain functional components of the sustainable development of industrial enterprises requires the need to involve not only quantitative but also qualitative indicators. Thus, as qualitative indicators for individual components can be accepted: economic component - the presence of a strategy of sustainable development of the enterprise, the level of corporate governance, the level of organization of production, the effectiveness of the organizational structure of management, the level of marketing, etc.; production component - the presence of a strategic plan for the technical development of the enterprise, the presence of a business plan, the effectiveness of the mechanism for managing the innovation activity of the enterprise, etc.; social component - the presence of a system of incentives for work, the presence of arrears of wages, satisfaction of workers with the level of wages, the presence of safe working conditions, the presence of conditions for rest, the level of labor protection, the level of industrial injury; environmental component - availability of a plan for the ecological development of production (environmental measures), the presence of toxic waste and emissions, compliance with the emissions of harmful substances norms and regulations (by types of pollutants), the use of resource-saving and low-waste technologies, the use of environmentally friendly raw materials, the availability of quality control alternatives types of energy and more. 


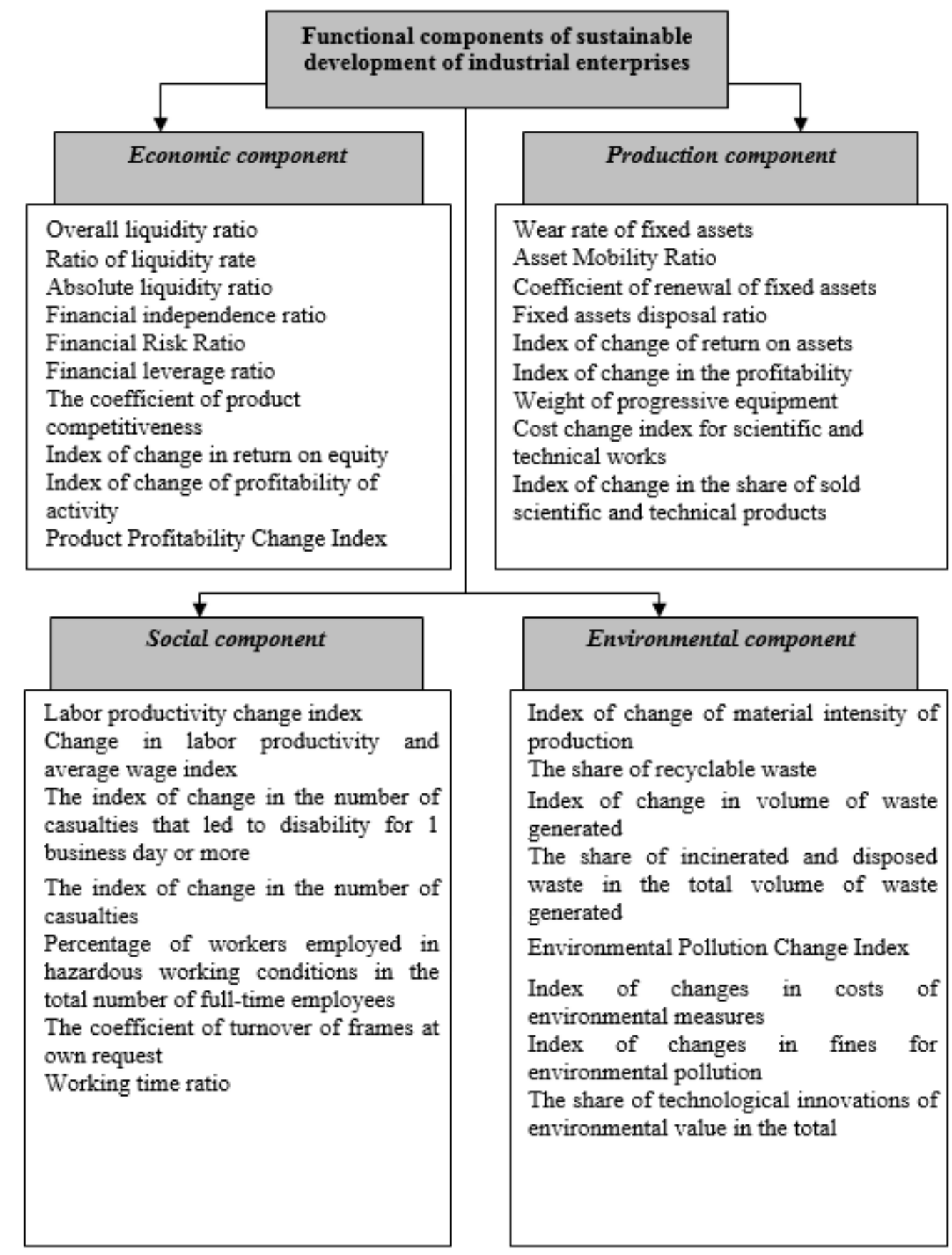

Fig.1. Components of sustainable development of industrial enterprises

For integrated assessment of the sustainable development of industrial enterprises, we propose a methodology based on the following provisions:

1) the aggregate index is the sum of the indices that characterize the economic, industrial, social and environmental component of the sustainable growth of industrial enterprises. In this case, each index has its specific weight;

2) the proportion of indices of individual functional components of sustainable development was determined taking into account their impact on the overall level of the indicator;

3) the index of each functional component is a grouping of quantitative and qualitative indicators;

4) quantitative indicators are normalized. The economicexpedient level of the indicator, or the level which is desirable for the particular enterprise of industry at a certain stage of its development is accepted as the normative one;

5) the aggregate index is determined not only by the size of certain quantitative indicators, but also by the direction of their changes;

6) qualitative indicators have only two fundamental values: "1" - the level of the indicator is satisfactory for the enterprise, or "0" - not satisfactory;

7) the normative values of the quantitative indicators and the satisfactory level of the qualitative indicators form the normative level of the aggregate index of sustainable development, which is taken as the basis of comparison;

8) to determine the deviations of the Sustainable Development Index from its normative level is based on factor analysis of the aggregate index. 
In general, the aggregate index of sustainable development of the enterprise is determined by the formula:

$$
I S D=0,39 I_{E S}+0,29 I_{S T S}+0,20 I_{S S}+0,12 I_{E G S},(1)
$$

where $I_{E S}$ - index that characterizes the impact of the economic component; $I_{S T S}$ - index characterizing the impact of a manufacturing component; $I_{S S}$ - index that characterizes the impact of a social component; $I_{E G S}$ index characterizing the impact of the environmental component.

The calculation formulas for determining the indices that characterize the individual components of the development of industrial enterprises are as follows:

$$
\begin{aligned}
& I_{E S}=\prod_{i=1}^{n}\left(N I_{i(+)}^{E S} / N I_{i(-)}^{E S}\right)+\sum_{j}^{m} Q I_{j}^{E S} * \beta_{j}^{E S} \\
& I_{S T S}=\prod_{i=1}^{n}\left(N I_{i(+)}^{S T S} / N I_{i(-)}^{S T S}\right)+\sum_{j}^{m} Q I_{j}^{S T S} * \beta_{j}^{S T S} \\
& I_{S S}=\prod_{i=1}^{n}\left(N I_{i(+)}^{S S} / N I_{i(-)}^{S S}\right)+\sum_{j}^{m} Q I_{j}^{S S} * \beta_{j}^{S S} \\
& I_{E G S}=\prod_{i=1}^{n}\left(N I_{i(+)}^{E G S} / N I_{i(-)}^{E G S}\right)+\sum_{j}^{m} Q I_{j}^{E G S} * \beta_{j}^{E G S},
\end{aligned}
$$

where $N I_{i(+)}^{E S}, N I_{i(+)}^{S T S}, N I_{i(+)}^{S S}, N I_{i(+)}^{E G S}$ - accordingly, the magnitude of the $i$-th quantitative indicator of the

Table 2 - Example of calculating the change in the value of an individual indicator and the aggregate index of sustainable development of the enterprise

\begin{tabular}{|l|c|c|c|}
\hline \multicolumn{1}{|c|}{ Characteristic } & $\begin{array}{c}\text { Standard } \\
\text { value }\end{array}$ & $\begin{array}{c}\text { Actual } \\
\text { value }\end{array}$ & Deviation \\
\hline Financial independence ratio & 0,50 & 0,67 & $+0,17$ \\
\hline Aggregated index & 5,2485 & 5,0537 & $-0,1948$ \\
\hline
\end{tabular}

The generalized results of the calculation of the separate influence of the factors that determine the index of economic component on the change in the aggregate indicator are given in Table. 3.

Table 3 - Factor analysis of the economic component

\begin{tabular}{|l|c|c|}
\hline \multicolumn{1}{|c|}{ Characteristic } & Factor change & $\begin{array}{c}\text { Separate effect on change in aggregate } \\
\text { metric }\end{array}$ \\
\hline Overall liquidity ratio & $-0,1$ & $-0,04809$ \\
\hline Ratio of liquidity rate & $-0,12$ & $-0,163507$ \\
\hline Absolute liquidity ratio & $-0,05$ & $-0,192361$ \\
\hline Financial independence ratio & 0,11 & $-0,187989$ \\
\hline Financial Risk Ratio & 0,05 & $-0,017717$ \\
\hline Financial leverage ratio & 0,1 & $-0,212971$ \\
\hline The coefficient of product competitiveness & $-0,1$ & $-0,153014$ \\
\hline Index of change in return on equity & $-0,11$ & $-0,105799$ \\
\hline Index of change of profitability of activity & $-0,12$ & $-0,108308$ \\
\hline Product Profitability Change Index & $-0,19$ & $-0,139462$ \\
\hline
\end{tabular}

economic, production, social and environmental component, the desired direction of change is increase;

$N I_{i(-)}^{E S}, N I_{i(-)}^{S T S}, N I_{i(-)}^{S S}, N I_{i(-)}^{E G S}$ - accordingly, the value of the $i$-th quantitative indicator of the economic, production, social and environmental component, the desirable direction of change of which is to reduce;

$Q I_{j}^{E S}, Q I_{j}^{S T S}, Q I_{j}^{S S}, Q I_{j}^{E G S}$ - respectively, the value of the $j$-th quality indicator of economic, production, social and environmental components;

$\beta_{j}^{E S}, \beta_{j}^{S T S}, \beta_{j}^{S S}, \beta_{j}^{E G S}$ - respectively the specific weight of the $j$-th qualitative indicator of economic, production, social and environmental components (determined by the condition $\sum_{j=1}^{m} \beta_{j}=1$ ).

According to the calculations, the indices of the individual functional components acquired the following values: $I_{E S}=1,6254, \quad I_{S T S}=1,2407, \quad I_{S S}=1,2228$, $I_{E G S}=1,1596$. Accordingly, the aggregate index of sustainable development of the enterprise is $I S D=5,2485$. Thus, the factors that characterize the economic component had the greatest impact on the value of the aggregate index of sustainable development of the enterprise. At the same time, a comparison of the actual values of the factors with their normative level made it possible to determine the change in the aggregate index (Table 2). 


\section{Conclusions}

Ensuring sustainable development of enterprises is an important characteristic and task of the current stage of development of domestic industry. The formation of a system for effective management of the sustainable development of an individual enterprise requires justification of the factors of influence. To this end, the economic, industrial, social and environmental functional components of sustainable development were investigated. The proposed methodology for integrated assessment is based on the use of quantitative and qualitative indicators of these components. the use of the proposed methodology allows: to calculate indices of sustainable development according to its separate functional components; to determine the normative value of the aggregate index of sustainable development of the enterprise; to carry out factor analysis taking into account deviations from the normative parameters of individual quantitative indicators or discrepancy of qualitative.

\section{References}

1. Monitorynhovyi zvit Derzhavnoi sluzhby statystyky ta Ministerstvo ekonomichnoho rozvytku i torhivli Ukrainy "Tsili staloho rozvytku: Ukraina" - 2019 rik [Monitoring report of the State Statistics Service and the Ministry of Economic Development and Trade of Ukraine "Sustainable Development Goals: Ukraine" - 2019 year]. Retrieved from http://www.ukrstat.gov.ua

2. Honchar, V.V., Filipishyna L.M. (2017). Rozrobka prohramy staloho ekonomichnoho rozvytku na osnovi hrupuvannia promyslovykh pidpryiemstv [Development of sustainable economic development program based on grouping of industrial enterprises]. Skhidna Yevropa: Ekonomika ta upravlinnia: Zbirnyk naukovykh prats Prydniprovskoi derzhavnoi akademii budivnytstva i arkhitektury - Eastern Europe: Economics and Management: Proceedings of the Pridneprovsk State Academy of Civil Engineering and Architecture, 4 (09), 146-150. Retrieved from http://www.easterneurope-ebm.in.ua/journal/9_2017/49.pdf

3. Halchak, H.R. (2016). Zabezpechennia staloho rozvytku pidpryiemstva yak osnova formuvannia sotsialnoi vidpovidalnosti [Ensuring sustainable development of the enterprise as a basis for the formation of social responsibility]. Visnyk Natsionalnoho universytetu "Lvivska politekhnika". Problemy ekonomiky ta upravlinnia - Bulletin of the National University "Lvivska politekhnika". Problems of economy and management, 847, 69-74. Retrieved from http://nbuv.gov.ua/UJRN/VNULPP_2016_847_13

4. Pokulin, S.L. (2016). Upravlinnia stalym rozvytkom suchasnoho pidpryiemstva [Management of sustainable development of modern enterprise]. Traektoryia nauky: Elektronnyi nauchnyi zhurnal - The trajectory of science: Electronic scientific journal, 3 (8).

5. Natsionalna dopovid "Tsili staloho rozvytku: Ukraina - 2017 rik" [National report "Sustainable Development Goals: Ukraine - 2017”. Retrieved from http://www.ukrstat.gov.ua 